\title{
Enzymatic Production of D-Glycerate from L-Tartrate
}

\author{
Setsuo Furuyoshi, ${ }^{*}$ Nariyoshi Kawabata, ${ }^{*}$ Hidehiko TanaKA ${ }^{\dagger}$ \\ and Kenji SODA ${ }^{\dagger \dagger}$ \\ Laboratory of Microbial Biochemistry. Institute for Chemical Research, \\ Kyoto University, Uji, Kyoto 611, Japan \\ * Department of Chemistry, Faculty of Engineering and Design, \\ Kyoto Institute of Technology, Matsugasaki, \\ Sakyo-ku, Kyoto 606, Japan \\ Received February 13, 1989
}

\begin{abstract}
D-Glyceric acid is a useful chiral synthon in synthetic organic chemistry. To produce D-glycerate cheaply, microorganisms that convert L-tartrate into D-glycerate with good yields and selectivity were isolated from soil samples. One microorganism obtained was identified as a strain of Pseudomonas sp. group Ve-2 and found to produce a new enzyme, L-tartrate decarboxylase. This enzyme catalyzes the direct conversion of L-tartrate into D-glycerate, with almost $100 \%$ selectivity. In the presence of a cellextract of Pseudomonas sp. group Ve-2, the amount of D-glycerate produced from L-tartrate reached $53 \mathrm{~g} / \mathrm{I}$ under the best conditions examined, with a molar yield of almost $100 \%$ and an optical purity of more than $92 \%$ e.e.
\end{abstract}

D-Glyceric acid is a useful chiral synthon in synthetic organic chemistry. ${ }^{1,2)}$ The best known method for the preparation of optically pure D-glyceric acid is the oxidation of $\alpha$ methyl-D-glucopyranoside, followed by hydrolysis. ${ }^{3)}$ However, it is rather complicated. D-Glyceric acid is alternatively obtained by optical resolution of its racemic form with penicillia or aspergilli. ${ }^{43}$

D-Glycerate is also synthesized in many microorganisms. In Pseudomonas putida ${ }^{5,6)}$ and Rhodopseudomonas sphaeroides, ${ }^{7)}$ D-glycerate is formed from L-tartrate by a coupled enzymatic system in the presence of catalytic amounts of $\mathrm{NAD}^{+}$and $\mathrm{Mn}^{2+}$. The first enzyme in this system, L-tartrate dehydrogenase ( $\mathrm{EC}$ 1.1.1.93), catalyzes the $\mathrm{NAD}^{+}$linked oxidation of L-tartrate to oxaloglycolate. ${ }^{8)}$ The formation of D-glycerate from oxaloglycolate and the oxidation of NADH are mediated by the second enzyme, oxaloglycolate reductive decarboxylase (EC 1.1.1.92). ${ }^{9 \text { ) }}$ $\mathrm{D}$-Glycerate is also produced from tartronic semialdehyde in $P$. ovalis, ${ }^{10)}$ and from hydroxypyruvate in Pseudomonas sp. ${ }^{11)}$ in the presence of equivalent amounts of NADH. However, D-glycerate production with microbial enzymes has not been developed industrially.

L-Tartrate is a cheap by-product of the wine industry and, therefore, is expected to be a good starting material for D-glycerate production. To produce D-glycerate cheaply, we have screened microorganisms that convert $\mathrm{L}$ tartrate into D-glycerate with good yields and selectivity. One microorganism obtained was found to produce a new enzyme, L-tartrate decarboxylase, which catalyzes the direct conversion of L-tartrate into D-glycerate, with almost $100 \%$ selectivity. ${ }^{12)}$ It seems reasonable to produce $\mathrm{D}$-glycerate from L-tartrate using this enzyme. In this paper, we describe the isolation of a microorganism that produces $\mathrm{L}^{-}$ tartrate decarboxylase, the formation of the enzyme and the simple enzymatic production of D-glycerate from L-tartrate, with emphasis

* Present address: Faculty of Agriculture, Okayama University, Okayama 700, Japan

if To whom all correspondence should be addressed. 
on the reaction conditions.

\section{Materials and Methods}

Materials. $\mathrm{NAD}^{+}$and $\mathrm{NADH}$ were purchased from Kohin Co., and glyoxylate reductase (EC 1.1.1.26, from spinach leaves) and diaphorase (EC 1.8.1.4, NADH: dye oxidoreductase, from Clostridium kluyveri) from Sigma Chemical $\mathrm{Co}$. Other chemicals used were the best available commercial products.

Screening of glycerate-producing microorganisms. LTartrate-assimilating microorganisms were obtained by using a medium containing $1.0 \%$ potassium L-tartrate, $0.3 \%\left(\mathrm{NH}_{4}\right)_{2} \mathrm{SO}_{4}, 0.3 \% \mathrm{~K}_{2} \mathrm{HPO}_{4}, 0.01 \% \mathrm{MgSO}_{4} \cdot 7 \mathrm{H}_{2} \mathrm{O}$ and $0.02 \%$ yeast extract. The $\mathrm{pH}$ was adjusted to 7.5 with $3 \mathrm{~N} \mathrm{HCl}$. This medium was used as the basal medium. A small amount of a soil sample was inoculated in $5 \mathrm{ml}$ of the basal medium. After aerobic cultivation at $25^{\circ} \mathrm{C}$ until growth was detected visually, the microorganisms were isolated on agar plates of the basal medium. The isolated bacteria were maintained on the basal medium supplemented with $2 \%$ agar.

Cells of a microorganism obtained were inoculated into $200 \mathrm{ml}$ of the basal medium in a $500 \mathrm{ml}$-flask. After aerobic cultivation at $25^{\circ} \mathrm{C}$ for $12 \mathrm{hr}$, the cells were harvested by centrifugation and then washed twice with $0.85 \% \mathrm{NaCl}$. The washed cells, about $1 \mathrm{~g}$ (wet weight), were suspended in $1 \mathrm{ml}$ of $0.1 \mathrm{M}$ Tris- $\mathrm{HCl}$ buffer $(\mathrm{pH} \mathrm{7.5)}$ and then subjected to sonication at $4^{\circ} \mathrm{C}$ for $2 \mathrm{~min}$ with a Seiko Instruments model 7040 ultrasonic disintegrator. After centrifugation $\left(40,000 \times g\right.$ for $20 \mathrm{~min}$ at $\left.4^{\circ} \mathrm{C}\right)$, the supernatant was used for glycerate production and the assay of L-tartrate dehydrogenase

Standard conditions for D-glycerate production. The standard reaction mixture for the production of glycerate contained $100 \mu \mathrm{mol}$ of Tris- $\mathrm{HCl}$ buffer (pH 7.5), $1 \mu \mathrm{mol}$ of $\mathrm{MgCl}_{2}, 1 \mu \mathrm{mol}$ of $\mathrm{NAD}^{+}, 50 \mu \mathrm{mol}$ of potassium L-tartrate and an appropriate amount of the cell-extract, in a final volume of $1.0 \mathrm{ml}$. After incubation at $30^{\circ} \mathrm{C}$ for $1 \mathrm{hr}, 0.2 \mathrm{ml}$ of $3 \mathrm{~N} \mathrm{HCl}$ was added. Tartrate and glycerate were determined by liquid chromatography using a TOSOH HLC-803D with an ULTRON PS-80H column $(0.8 \times 30 \mathrm{~cm}$; Shinwa Kako Co. $)$. Elution was carried out with $0.126 \% \mathrm{HClO}_{4}$ at the flow rate of $0.8 \mathrm{ml} / \mathrm{min}$. The elution times of tartrate and glycerate were $9.2 \mathrm{~min}$ and $11.1 \mathrm{~min}$, respectively.

Analytical methods. The experimental conditions for the assay of L-tartrate decarboxylase were identical to those for glycerate production. One unit of the enzyme was defined as the amount of enzyme that catalyzed the appearance of $1 \mu \mathrm{mol}$ of D-glycerate per min.

L-Tartrate dehydrogenase activity was assayed with a Shimadzu UV-3000 spectrophotometer, with the cell com- partment thermostatically maintained at $30^{\circ} \mathrm{C}$. The standard assay mixture for the measurement of L-tartrate dehydrogenase was the same as the standard reaction mixture for glycerate production, in a total volume of $1.0 \mathrm{ml}$. The reaction was started by the addition of enzyme to the reaction mixture previously incubated at $30^{\circ} \mathrm{C}$. The quantity of the enzyme used was such that there would be a linear change in the absorbance at $340 \mathrm{~nm}$ for at least $2 \mathrm{~min}$. One unit of the enzyme was defined as the amount of enzyme that catalyzed the appearance of $1 \mu \mathrm{mol}$ of NADH per min. Specific activity was expressed as units per mg of protein.

Protein was determined by the method of Lowry et al. ${ }^{13)}$ with crystalline bovine serum albumin as a standard.

\section{Results and Discussion}

Screening of glycerate-producing microorganisms

To produce D-glycerate cheaply, initially, microorganisms that convert L-tartrate into glycerate in good yields were screened. Among the $\mathrm{L}$-tartrate-assimilating microorganisms obtained, cells of 7 strains were found to produce enzyme(s) that convert $\mathrm{L}$-tartrate into glycerate. Although L-tartrate dehydrogenase activity was found in cell-extracts of the $7 \mathrm{mi}$ croorganisms, no relationship was found between the L-tartrate dehydrogenase activity and the glycerate-producing activity (Table I). Since the best yield of glycerate and the best

Table I. SCREening of Glycerate-Producing MiCROORGANISMS

The reaction was carried out in the standard reaction mixture at $30^{\circ} \mathrm{C}$ for an hour. The reaction mixture contained $0.1 \mathrm{ml}$ of the cell extract obtained, in a total. volume of $1 \mathrm{ml}$.

\begin{tabular}{|c|c|c|c|c|}
\hline \multirow[b]{2}{*}{ Strain } & \multirow{2}{*}{$\begin{array}{c}\text { Cell } \\
\text { yield } \\
\text { (wet } \\
\text { weight, } \\
\mathrm{g} / 200 \mathrm{ml} \text { ) }\end{array}$} & \multicolumn{2}{|c|}{$\begin{array}{l}\text { Glycerate-producing } \\
\text { activity }\end{array}$} & \multirow{2}{*}{$\begin{array}{c}\text { Total } \\
\text { L-tartrate } \\
\text { dehydrogenase } \\
\text { activity } \\
\text { (milliunits) }\end{array}$} \\
\hline & & $\begin{array}{c}\text { Glycerate } \\
\text { formed } \\
(\mu \mathrm{mol})\end{array}$ & $\begin{array}{c}\text { Tartrate } \\
\text { consumed } \\
(\mu \mathrm{mol})\end{array}$ & \\
\hline $507 \mathrm{~B}$ & 0.66 & 29 & 30 & 8 \\
\hline $509 \mathrm{~B}$ & 0.69 & 21 & 21 & 8 \\
\hline $5 \mathrm{DIA}$ & 0.49 & 38 & 38 & 16 \\
\hline 5D8A & 0.56 & 23 & 37 & 21 \\
\hline $5 D 13 B$ & 0.70 & 13 & 13 & 6 \\
\hline $704 \mathrm{~A}$ & 0.52 & 23 & 27 & 21 \\
\hline $7 \mathrm{D} 10 \mathrm{C}$ & 0.20 & Trace & Trace & 10 \\
\hline
\end{tabular}


Table II. TAXONOMIC Characteristics of STrain 5DIA

\begin{tabular}{|c|c|}
\hline Flagella & Polar 1 \\
\hline Motility & Motile by polar flagella \\
\hline Shape & Rod, $0.8 \sim 1.2 \times 2.0 \sim 3.2 \mu \mathrm{m}$ \\
\hline Gram strain & Negative \\
\hline Oxidase test & Negative \\
\hline Catalase test & Positive \\
\hline \multicolumn{2}{|l|}{ Growth } \\
\hline anaerobic & Negative \\
\hline $37 / 41^{\circ} \mathrm{C}$ & Positive/negative \\
\hline Pigments & Yellow-orange (non-diffusible) \\
\hline $\mathrm{O}-\mathrm{F}$ test & Oxidative \\
\hline Gas from glucose & Negative \\
\hline$\beta$-Galactosidase test & Negative \\
\hline Indol production & Negative \\
\hline Nitrate reduction & Negative \\
\hline Denitrification & Negative \\
\hline Phenylalanine deaminase & Positive \\
\hline Levan from sucrose & Negative \\
\hline Lecithinase test & Negative \\
\hline Urease test & Negative \\
\hline \multicolumn{2}{|l|}{ Hydrolysis of } \\
\hline starch & Positive \\
\hline gelatin & Negative \\
\hline casein & Negative \\
\hline DNA & Negative \\
\hline Tween 80 & Negative \\
\hline esculin & Negative \\
\hline Tyrosine degradation & Negative \\
\hline Growth factor & None \\
\hline \multicolumn{2}{|c|}{ Carbon source utilization test } \\
\hline \multicolumn{2}{|c|}{$\begin{array}{l}\text { Utilized: acetate, caprate, citrate, malate, malonate, } \\
\text { L-arabinose, fructose, glucose, mannose, maltose, } \\
\text { xylose, mannitol, gluconate, } 2 \text {-ketogluconate, L- } \\
\text { serine. }\end{array}$} \\
\hline $\begin{array}{l}\text { Not utilized: adipate, g } \\
\text { phenylacetate, } N \text {-ace }\end{array}$ & $\begin{array}{l}\text { lycolate, levulinate, } \\
\text { tylglucosamine. }\end{array}$ \\
\hline
\end{tabular}

selectivity, almost $100 \%$, were obtained with the cell-extract of strain 5D1A, this strain was used for further experiments. The taxonomic characteristics of the strain are shown in Table II. Although this strain did not correspond to any species described in the 8th edition of Bergey's Manual of Determinative Bacteriology, ${ }^{14)}$ it was identified as a strain of Pseudomonas sp. group $\mathrm{Ve}-2$ according to the 4 th edition of the Manual of Clinical Microbiology. ${ }^{15)}$

\section{Identification of the product}

To identify the reaction product and to determine its steric configuration, the product was isolated from the reaction mixture. The cell-extract of strain 5D1A (containing $938 \mathrm{mg}$ of protein) was added to 11 of $20 \mathrm{~mm}$ Tris- $\mathrm{HCl}$ buffer ( $\mathrm{pH} 7.5$ ) containing $100 \mathrm{mmol}$ of potassium L-tartrate, $2 \mathrm{mmol}$ of $\mathrm{NAD}^{+}$and $0.2 \mathrm{mmol}$ of $\mathrm{MgCl}_{2}$. On incubation at $30^{\circ} \mathrm{C}$ for $24 \mathrm{hr}$, L-tartrate was converted into glycerate completely. Then the reaction mixture was applied to an Amberlite IRA-400 (OH form) column $(5 \times 21 \mathrm{~cm})$. The column was washed with 11 of $\mathrm{H}_{2} \mathrm{O}$ and then the glycerate was eluted with 11 of $1 \mathrm{~N} \mathrm{HCl}$. The solution was concentrated in vacuo and the glycerate hemicalcium salt (dihydrate) was obtained according to the method of Baer et al. ${ }^{16)}$ The purity of the glycerate hemicalcium salt obtained was estimated to be almost $100 \%$ by highperformance liquid chromatography.

The reaction product and authentic DLglycerate showed the same retention time on high-performance liquid chromatography. The nuclear magnetic resonance and infra-red spectra of the product also showed the same patterns as those of the authentic DL-glycerate hemicalcium salt. The specific optical rotation value $\left([\alpha]_{D}^{20}\right)$ of the product was +13.3 (reported $[\alpha]_{D}^{20}$ values for D-glycerate hemicalcium, $+12.9 \sim+15.5^{17)}$ ). About $96 \%$ of the reaction product reacted with glyoxylate reductase and $\mathrm{NAD}^{+}$to yield NADH on $24 \mathrm{hr}$ incubation at $25^{\circ} \mathrm{C}$. Glyoxylate reductase, from spinach leaves, catalyzes the $\mathrm{NAD}^{+}$dependent oxidation of $\mathrm{D}$-glycerate but does not act on the L-isomer. ${ }^{18}$ ) The formation of $\mathrm{NADH}$ was followed at $546 \mathrm{~nm}$ as the formation of formazan dye of $p$-nitrotetrazolium blue by diaphorase. ${ }^{7}$ Because the equilibrium of D-glycerate oxidation lies so far to the side of formation of D-glycerate, ${ }^{18)}$ it is difficult to oxidize $\mathrm{D}$-glycerate into $\beta$-hydroxypyruvate completely. Therefore, the optical purity of the product was estimated to be more than $92 \%$ e.e. Thus, the reaction product was identified as D-glycerate.

Enzyme participating in the conversion of $\mathrm{L}$ tartrate into D-glycerate

In $P$. putida, D-glycerate is formed from $\mathrm{L}$ - 
Table III. Substrate SPECIFICITY OF THF Cell-extract

\begin{tabular}{lc}
$\begin{array}{c}\text { Substrate } \\
(50 \mathrm{mM})\end{array}$ & $\begin{array}{c}\text { Relative value } \\
(\%)\end{array}$ \\
\hline L-Tartrate & 100 \\
meso-Tartrate & 12 \\
D-Tartrate & 0 \\
DL-Malate & 0 \\
Dihydroxyfumarate & 0 \\
\hline
\end{tabular}

a $\mathrm{NADH}(10 \mathrm{~mm})$ was used in the place of $\mathrm{NAD}^{+}$

tartrate through the actions of two enzymes, Ltartrate dehydrogenase and oxaloglycolate reductive decarboxylase. ${ }^{5,6)}$ To elucidate whether the enzyme(s) participating in D-glycerate production is the same as that of $P$. putida or a new one, we investigated the substrate specificity of the cell-extract of strain 5D1A (Table III). D-Glycerate was also formed from mesotartrate, but not from D-tartrate. Although Ltartrate dehydrogenase activity was found in the cell-extract (Table I), dihydroxyfumarate, the enolic isomer of oxaloglycolate, was not converted into D-glycerate in the presence of $10 \mathrm{~mm}$ NADH. Thus the enzyme participating in the conversion of L-tartrate into D-glycerate from Pseudomonas sp. 5D1A was different from that of $P$. putida. ${ }^{9)}$ We have purified the enzyme to homogeneity and proved that it is a new enzyme, L-tartrate decarboxylase which catalyzes the direct conversion of L-tartrate into D-glycerate, through additional experiments. ${ }^{12)}$ The L-tartrate dehydrogenase activity observed with the cell-extract of strain 5D1A was due to a side reaction catalyzed by L-tartrate decarboxylase. The detailed properties of the enzyme will be described elsewhere.

\section{Formation of $\mathrm{L}$-tartrate decarboxylase}

To establish the most effective medium for the enzyme formation, the effects of several carbon sources on the formation of the $\mathrm{L}^{-}$ tartrate decarboxylase by strain 5D1A cells were examined using the basal medium. The best cell yield and the highest L-tartrate decarboxylase activity were observed with Ltartrate as a sole carbon source (Table IV).
Table IV. EfFects of Carbon Sources on the Formation OF L-TaRTRATE DECARboXYLASE

\begin{tabular}{lc}
$\begin{array}{c}\text { Carbon source } \\
(0.5 \%)\end{array}$ & $\begin{array}{r}\text { L-Tartrate decarboxylase } \\
\text { (units/mg protein) }\end{array}$ \\
\hline L-Tartrate & 0.21 \\
meso-Tartrate & 0.063 \\
D-Tartrate & 0.029 \\
Glycerol & 0 \\
\hline
\end{tabular}

Table V. EFFects of Various Divalent Cations on d-Glycerate Production

The reaction was carried out at $30^{\circ} \mathrm{C}$ for $1 \mathrm{hr}$ as described in the text except that $\mathrm{MgCl}_{2}$ was replaced by other metals, as indicated. The reaction mixtures contained $3.2 \mathrm{mg}$ of protein, in a total volume of $1 \mathrm{ml}$.

\begin{tabular}{lc}
$\begin{array}{c}\text { Metal } \\
(1 \mathrm{mM})\end{array}$ & $\begin{array}{c}\text { Relative activity } \\
(\%)\end{array}$ \\
\hline None & 100 \\
$\mathrm{MgCl}_{2}$ & 158 \\
$\mathrm{MnCl}_{2}$ & 145 \\
$\mathrm{CoCl}_{2}$ & 101 \\
$\mathrm{CaCl}_{2}$ & 92 \\
$\mathrm{NiSO}_{4}$ & 86 \\
$\mathrm{FeSO}_{4}$ & 34 \\
$\mathrm{CuCl}_{2}$ & 15 \\
$\mathrm{ZnSO}_{4}$ & 2 \\
$\mathrm{EDTA}$-treated & 0 \\
\hline
\end{tabular}

Thus L-tartrate is the best inducer of L-tartrate decarboxylase.

\section{Establishment of the optimal reaction conditions} for D-glycerate production

To produce D-glycerate most economically, the optimal conditions for D-glycerate production were examined with the cell-extract of Pseudomonas sp. strain 5D1A. The optimal $\mathrm{pH}$ and temperature for the D-glycerate production from L-tartrate were 7.0 to 8.0 and around $30^{\circ} \mathrm{C}$, respectively, on $3 \mathrm{hr}$ incubation.

The L-tartrate decarboxylase was affected by the addition of various metal ions. The enzyme was activated by the addition of $\mathrm{Mg}^{2+}$ or $\mathrm{Mn}^{2+}$, and inactivated by $\mathrm{Fe}^{2+}, \mathrm{Zn}^{2+}$ or $\mathrm{Cu}^{2+}$ (Table V). The cell-extract of strain 5D1A completely lost its L-tartrate decarboxylase activity on incubation with $1 \mathrm{~mm}$ EDTA at $30^{\circ} \mathrm{C}$ for $1 \mathrm{hr}$. The inactivated L-tartrate de- 


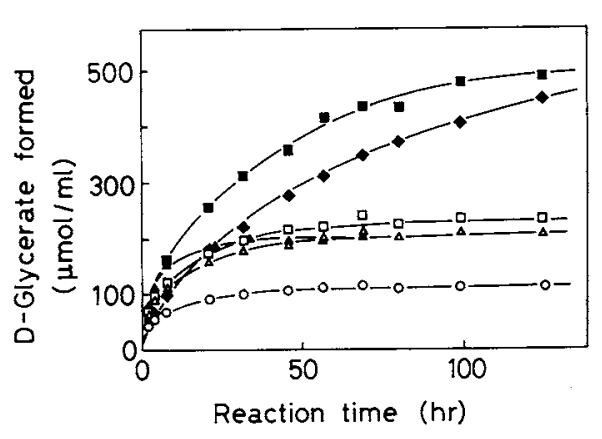

Fig. 1. Time Course of D-Glycerate Production.

The reaction mixture contained, in $2 \mathrm{ml}$ : Tris- $\mathrm{HCl}$ buffer (pH 7.5), $200 \mu \mathrm{mol} ; \mathrm{MgCl}_{2}, 0.4 \mu \mathrm{mol}$; cell-extract (protein, $2.37 \mathrm{mg}$ ); $\mathrm{NAD}^{+}, 2 \mu \mathrm{mol}(\mathrm{O}), 4 \mu \mathrm{mol}(\triangle, \square)$ or $20 \mu \mathrm{mol}$ $(\Delta, \square, \Delta)$; and potassium L-tartrate, $200 \mu \mathrm{mol}(\mathrm{O})$, $400 \mu \mathrm{mol}(\triangle, \boldsymbol{\Delta}), 1 \mathrm{mmol}(\square, \boldsymbol{\square})$ or $2 \mathrm{mmol}(\bullet)$. The Dglycerate formed and residual L-tartrate were assayed in $0.05 \mathrm{ml}$ aliquots.

carboxylase was nearly reactivated by the addition of $1 \mathrm{mM} \mathrm{MgCl}_{2}$ or $\mathrm{MnCl}_{2}$. The effect of $\mathrm{MgCl}_{2}$ was almost constant at concentrations of $0.2 \mathrm{~mm}$ and over.

\section{Time course of D-glycerate production}

Figure 1 shows the time course of Dglycerate production from L-tartrate with various concentrations of $\mathrm{L}$-tartrate and $\mathrm{NAD}^{+}$. The reaction rates and the final yields of $D-$ glycerate increased with increasing concentrations of $\mathrm{NAD}^{+}$. The yields of $\mathrm{D}$-glycerate produced under the optimal reaction conditions from 100 and $200 \mu \mathrm{mol} / \mathrm{ml}$ of L-tartrate in the presence of 1 and $2 \mu \mathrm{mol} / \mathrm{ml}$ of $\mathrm{NAD}^{+}$, respectively, reached nearly $100 \%$. However, only $220 \mu \mathrm{mol} / \mathrm{ml}$ of D-glycerate was formed from $500 \mu \mathrm{mol} / \mathrm{ml}$ of $\mathrm{L}$-tartrate in the presence of $2 \mu \mathrm{mol} / \mathrm{ml}$ of $\mathrm{NAD}^{+}$in $120 \mathrm{hr}$. The reaction had ceased by that time. However, it recommenced, at half the initial rate, on the addition of $2 \mu \mathrm{mol} / \mathrm{ml}$ of $\mathrm{NAD}^{+}$. In the presence of $10 \mu \mathrm{mol} / \mathrm{ml}$ of $\mathrm{NAD}^{+}, 500 \mu \mathrm{mol} / \mathrm{ml}$ of $\mathrm{L}^{-}$ tartrate was converted completely into $\mathrm{D}$ glycerate. Although the L-tartrate decarboxylase requires $\mathrm{NAD}^{+}$as a cofactor, ${ }^{12)}$ no net reduction was observed through the reaction. Thus the dependence of the final yield on the concentration of $\mathrm{NAD}^{+}$may be due to decom- position of $\mathrm{NAD}^{+}$. When $1 \mathrm{mmol} / \mathrm{ml}$ of $\mathrm{L}^{-}$ tartrate was used as a substrate, strong substrate inhibition was observed (Fig. 1).

We described here the simple enzymatic production of D-glycerate from L-tartrate by the cell-extract of Pseudomonas sp. 5D1A. We are currently developing a new system for preparing D-glycerate with immobilized cells.

\section{References}

1) C. H. Wong and J. R. Matos, J. Org. Chem., 50, 1992 (1985).

2) H. Takayama, M. Ohmori and S. Yamada, Tetrahedron Lett., 21, 5027 (1980).

3) L. F. Fieser and M. Fieser, "Reagents for Organic Synthesis," John Wiley and Sons, Inc., New York, 1967, p. 815.

4) A. McKenzie and A. Harden, J. Chem. Soc., 83, 424 (1903).

5) L. D. Kohn and W. B. Jakoby, Biochem. Biophys. Res. Commun., 22, 33 (1966).

6) L. D. Kohn and W. B. Jakoby, J. Biol. Chem., 243, 2465 (1968).

7) H. Ebbighausen and F. Giffhorn, Arch. Microbiol, 138, 338 (1984).

8) L. D. Kohn, P. M. Packman, R. H. Allen and W. B. Jakoby, J . Biol. Chem., 243, 2479 (1968).

9) L. D. Kohn and W. B. Jakoby, J. Biol. Chem., 243, 2486 (1968).

10) A. M. Gotto and H. L. Kornberg, Biochem. J., 81, 273 (1961).

11) L. D. Kohn and W. B. Jakoby, J. Biol. Chem., 243, 2494 (1968).

12) S. Furuyoshi, N. Kawabata, H. Tanaka and K. Soda, the Annual Meeting of the Japanese Biochemical Society, Tokyo, October, 1988, p. 792.

13) O. H. Lowry, N. J. Rosebrough, A. L. Farr and R. J. Randall, J. Biol. Chem., 193, 265 (1951).

14) "Bergey's Manual of Determinative Bacteriology," 8th Ed., M. Doudoroff and N. J. Palleroni, Williams \& Wilkins Co., Baltimore, 1974, p. 217.

15) "Manual of Clinical Microbiology," 4th Ed., ed. by E. H. Lennette, A. Balows, W. J. Hausler, Jr. and H. J. Shadomy, American Society for Microbiology, Washington, D.C., 1985, p. 370.

16) E. Baer, J. M. Grosheintz and H. O. L. Fischer, J. Am. Chem. Soc., 61, 2607 (1939).

17) "Data for Biochemical Research," 2nd Ed., ed. by R. M. C. Dawson, D. C. Elliott, W. H. Elliott and K. M. Jones, Oxford University Press, Oxford, 1969, p. 80 .

18) L. D. Kohn and W. A. Warren, J. Biol. Chem., 245, 3831 (1970). 